\title{
THE DYNAMICS OF GROWTH AND FLOWERING OF INVASIVE SOLIDAGO SPECIES
}

\author{
Magdalena Szymura, Tomasz H. Szymura
}

\begin{abstract}
M. Szymura, Department of Agroecosystems and Green Areas Management, Wrocław University of Environmental and Life Sciences, pl. Grunwaldzki 24a, 50-363 Wrocław, Poland, e-mail: magdalena. szymura@up.wroc.pl

T.H. Szymura, Department of Ecology, Biogeochemistry and Environmental Protection, University of Wrocław, Kanonia 6/8, 50-328 Wrocław, Poland, e-mail: tomasz.szymura@uwr.edu.pl
\end{abstract}

(Received: April 17, 2015. Accepted: June 22, 2015)

\begin{abstract}
Aвstract. Solidago species are one of the most widespread invasive species in Europe. In Central Europe, vegetation dominated by alien goldenrods can occupy vast areas. Their presence causes a decrease in the biodiversity level of numerous groups of organisms (plants, birds and insects). Alien Solidago also disturb biogeochemical cycles, as well as the primary productivity in infested ecosystems. In Central Europe, four alien Solidago species are considered as naturalized plants: late goldenrod (Solidago altissima L.), Canadian goldenrod (S. canadensis L.), tall goldenrod (S. gigantea Aiton), and grass-leaved goldenrod (S. graminifolia (L.) Elliot. = Euthamia graminifolia (L.) Nutt.). To analyse the dynamics of the growth and flowering of Solidago species, an experiment was conducted in which the goldenrods were planted in pots. We examined the life history traits, which are treated as being strongly connected with the invasive abilities of these species. The height, number of ramets and percentage of flowered plants were noted at ten-day intervals from May to November over a period of four years. Two native species, often co-occurring with alien goldenrods, were analysed for comparison: European goldenrod (Solidago virgaurea L.) and common tansy (Tanacetum vulgare L.). The analysed species reached their maximal height during the second and third years of the experiment. The highest ramets were noted in the case of Solidago altissima, S. canadensis and S. gigantea. A group of lower plants consisted of Solidago graminifolia, together with the native species S. virgaurea and T. vulgare. The number of ramets formed by $S$. graminifolia was more than two times larger than in the case of other species. All of the analysed species flowered during the time of observation but, grass-leaved goldenrod, was the only one among the alien species which flowered in all pots and $100 \%$ of individuals produced mature seeds. Its phenology (early flowering and seed ripening) was more similar to native species' than to other alien Solidago. Our results suggest Solidago graminifolia has strong competitive abilities; however, its range is very limited. The reasons for the slow spread of this species in Europe - other than competitive limitations - should be considered.
\end{abstract}

KEY WORDS: alien species, goldenrods, phenology, growth dynamics

\section{INTRODUCTION}

Biological invasions, together with fragmentation and degradation of natural ecosystems, are the most serious threats to biodiversity on a global scale (VITOUSEK et al. 1997, SimBerloff et al. 2013). The introduction of alien species intensified in the 16th century. The discovery of America by Cristopher Columbus in 1492 is referred to as a dividing date. Subsequent to this date, many species were introduced from America to Europe and the same conversely. They are called neophytes which are contrary to species introduced earlier, the so-called archaeophytes (РYšEK et al. 2004, 2005). The shift from perceiving alien species as interesting components of ecosystems to recognising them as worrying weeds occurred relatively recently, approximately 50 years ago (РҮร̌EK \& RICHARDSON 2008). Since the development of studies on widely-distributed alien species, a new branch of ecology known as invasion ecology has emerged. At present, the main practical aim of this discipline is to prevent biological invasion and eradicate invasive 
species. For these purposes, knowledge about invasive species, particularly traits which cause that they are invasive, is necessary (Groves 1991, vaN KLEUNEN \& Richardson 2007, Schlaepfer et al. 2010).

Numerous studies have tried to answer the question concerning which traits enable species to invade new habitats. This knowledge allows the indication of potentially invasive species for restrictions on transport or early eradication (ALPERT et al. 2000, Moravcová et al. 2015). Plants which are expansive in their natural range, are widespread or have tendencies to grow in monocultures, are considered as potentially invasive (LAKE \& LeISHMAN 2004). Fast growth and production of numerous reproductive offsprings which are easily dispersed by humans and animals are characteristics related to invasiveness (BAKer 1974, RejmáneK \& Richardson 1996). Some life history traits connected with high competitive and reproductive abilities of a species (e.g. height of plants, production of numerous seeds, toxicity) are considered as characterising successful invaders (Schmid et al. 1988, SutHerland 2004). The small-scale spread of perennial plants depends mainly on vegetative reproduction by clonal growth (ERIKSson 1989). Clonal plants are generally more plastic (CHePlick 1995), which is a significant advantage in a new range and changing local conditions. Sexual reproduction and production of numerous widely-dispersed seeds is important in the colonization of new sites on a large scale (Meyer \& Schmid 1999). In the case of sexual reproduction, the synchronization of phenology is important, particularly flowering time with seasons in a new range and especially the period of wild pollinators' activity (PILsON 2000).

Species from the Solidago genus are one of the most widespread invasive species in Europe. Their presence causes a decrease in the number of vascular plants species, bird species, bird nesting pairs and biodiversity of wild pollinators (DE GROOT et al. 2007, Moroń et al. 2009, SKórKA et al. 2010). Alien Solidago disturb biogeochemical cycles as well as the primary productivity of infested ecosystems (SCHARFY et al. 2009). In Central Europe, four alien Solidago species are considered as naturalized plants: late goldenrod (Solidago altissima L. $=$ S. canadensis var. scabra (Muhl.) Torr. and Gray), Canadian goldenrod (S. canadensis L.), tall goldenrod (S. gigantea Aiton), and grass-leaved goldenrod (S. graminifolia (L.) Elliot. = Euthamia graminifolia (L.) Nutt.) (Schmid et al. 1988, RotHMALER 2007, RUTKOWSKI 2013). However, the taxonomical status of goldenrods which occur in Europe is still a problematic issue. The relationship between S. canadensis and S. altissima is particularly unclear. These species in many articles are reported as two varieties of $S$. canadensis s.l.: var. canadensis and var. scabra (GuzIKowa \& Maycock 1986, Weber 1997, WeBer \& SChmid 1998). Semple (personal information) suggests that Solidago altissima does not occur in Eu- rope at all. The taxon with hairier, lower stems than S. canadensis var. canadensis appears to be more similar to S. canadensis var. hargeri Fern. Moreover, Schmid et al. (1988), on the basis of analysis of American populations, define that $S$. altissima is more similar in life history traits to S. gigantea, and S. canadensis seems to be a separate taxon.

Goldenrods were introduced from North America in the second half of the 18th century as ornamental plants. After a short time, they 'escaped' from cultivation and spread across Europe. The occurrence of Solidago gigantea in Poland was reported earlier (in 1853) than S. canadensis s.l. (1872), and its invasion had also been observed twenty years earlier. Solidago graminifolia was introduced at a similar time to the aforementioned taxa (ToKARSKA-GuZIK 2003). Despite the extended period of time which has elapsed since their introduction, the expansion of alien goldenrods is still being observed across Europe (Weber 2001, SZYMURA \& SZYMURA 2011). Solidago genus is one of the most-studied plant genera in the native range in North America, and in the invasive range in Europe (e.g. Melville \& Morton 1982, Weber 1997, Weber \& Schmid 1998, Abrahamson et al. 2005). Unfortunately, little is still known about their comparative biology (Schmid et al. 1988).

The aims of the study were to examine: the dynamics of growth (changes in ramets' height during growing season), vegetative reproduction ability (the number of new ramets), and the percentage of flowered plants producing mature seeds in the case of generative reproduction), as well as the phenology of alien Solidago species which occur in Central Europe. For comparison, the same traits were analysed within native species Solidago virgaurea and Tanacetum vulgare - a perennial species which co-occur commonly with Solidago stands.

\section{MATERIALS AND METHODS}

The garden experiment was conducted in a station belonging to the Wrocław University of Environmental and Life Sciences located in Wrocław (N $51^{\circ} 6^{\prime} 54$, E $17^{\circ} 7^{\prime} 42$ ), at an altitude of $115 \mathrm{~m}$ a.s.l. The average annual temperature is $9.0^{\circ} \mathrm{C}$ (July $18.8^{\circ} \mathrm{C}$, January $-0.4^{\circ} \mathrm{C}$ ) and the average annual precipitation is $583 \mathrm{~mm}$, with the maximum falling between July and August. The length of the growing season is 226 days (DUBICKI et al. 2002).

The dynamics of the growth and flowering of five Solidago species (S. altissima, S. canadensis, S. gigantea, S. graminifolia, S. virgaurea) and Tanacetum vulgare were analysed. Seeds from populations located near Wrocław were collected. Twenty four populations per species were sampled. The sites from which the seeds were collected represent ruderal vegetation - mostly large stands of Solidago overgrowing in abandoned fields and marginal habitats such as road 
verges or along fences. Usually in the particular site a single Solidago species was found. Seeds of given species were mixed and sown in the experimental station in April. After germination, small plants were transplanted into plastic pots. The pots were placed outdoors and filled with local soil (Anthropic Regosols, loamy sand texture, $\mathrm{pH}$ in $\mathrm{KCl}$ 4.6-6.0). Manual removal of weeds and irrigation was applied but no fertilisation was used during growing seasons. During winter, the pots were covered to protect them from frost.

One individual of each studied species per pot was planted in 10 replications per species. Pots within species were arranged randomly. Growth and flowering were observed from May to October for over four years. In the last year of the experiment, the observations were finished earlier, i.e. in the middle of October. Every ten days, the height of the plants, the number of ramets and phenological phases were noted. The phenological phases were described in the following classes: 0 - only vegetative shoots, 1 - appearance of generative shoots or buds of flowers, 2 - beginning of flowering (less than $50 \%$ buds sprouted), 3 - hight flowering (more than $50 \%$ buds sprouted), 4 - late flowering (appearance of first seeds), 5 - seedset (more than $50 \%$ of seeds).

\section{RESULTS}

During the first season, plants accommodated to a new environment, grew slowly and reached their maximal height in the second half of growing season (Fig. 1). In the second and third years, the initial growth was faster. The tallest species was Solidago altissima; however, S. gigantea was able to reach a similar height. During the first year, S. canadensis reached a height similar to the group of lower species which represent: S. virgaurea, Tanacetum vulgare and Solidago graminifolia. During the course of the experiment, the differences in average height between S. canadensis, S. altissima and S. gigantea diminished. Observed at the end of growing seasons, in October (observation term no. 16-18) the decrease in average height of some species (e.g. Tanacetum vulgare, Solidago virgaurea and S. canadensis) was a result of senescence and decaying ramets.

The number of ramets was relatively low in the first year of observations within all observed taxa (Fig. 2). Their number was gradually increasing during the experiment and was highest in the final year. In the case of invasive Solidago species, the number of ramets was relatively high immediately at the beginning of each growing season, while the ramets' number of S. virgaurea and Tanacetum vulgare, initially low, increased gradually during season (Fig. 2). The number of ramets of Solidago graminifolia was more than two times higher than the remaining species, with the exception of the first growing season. Dur- ing the experiment, the number of ramets of Tanacetum vulgare was the lowest in spite of the fact that in the first year the number of ramets of this species was highest. In the majority of invasive species ( $S$. altissima, S. canadensis, S. graminifolia), a fluctuation in ramet production was observed. At the beginning of vegetation season, new shoots appeared and slowly decayed with time, while the other ones were produced during the season.

All analysed species flowered and produced ripe seeds during the experiment. In the first year, the generative shoots or buds of flowers were produced relatively late and a considerable proportion of plants were not able to seedset, among them all individuals of Solidago graminifolia (Fig. 3). The following years' plants started to develop inflorescences earlier and all of the species produced mature seeds. The exception was S. canadensis, which did not produce any inflorescence in the last year of the experiment. The percentage of plants producing mature seeds was high and in the case of S. graminifolia, all individuals flowered and produced seeds. The exception was S. canadensis whose maximal percentage of seedset plants was $60 \%$, but usually much less. In general, the invasive species, with the exception of $S$. graminifolia, flowered later than native ones. It was observed that $S$. virgaurea distinguished itself by another pattern of flowering and seedset. Some of the shoots ripened relatively early and the species was able to produce seeds for most of a growing season. Invasive species usually started flowering relatively later and the period of flowering was shorter than S. virgaurea (Fig. 3).

\section{DISCUSSION}

It is hard to identify traits that unquestionably are responsible for invasiveness in spite of numerous studies devoted to this problem (e.g. BAKER 1974, SCHMid et al. 1988, EriKsson 1989, CHEPLICK 1995, PYšEK et al. 1995, REJMÁNEK \& RiCHARDSON 1996, Goodwin et al. 1999, Meyer \& Schmid 1999, LAKe \& Leishman 2004, Sutherland 2004). One of the reasons is that different traits favour invasiveness in various habitats and stages of invasion (AlPERT et al. 2000, Moravcová et al. 2015). Species which were examined in our experiment and settled in similar habitats (S. altissima, S. canadensis and S. gigantea) mainly abandoned fields and marginal habitats - represent the same stage of invasion.

The species from Solidago genus exhibit high phenotypical plasticity related to environmental conditions (Weber 1997, Weber \& Schmid 1998). Garden experiments are commonly used to reduce the influence of the environment on plants' morphology (WALCK et al. 1999, van Kleunen \& Schmid 2003, Moloney et al. 2009). In the native range of goldenrods in America, the height of the ramets varies from 50 to $200 \mathrm{~cm}$ in the case of Solidago altissima and S. gigantea, and 


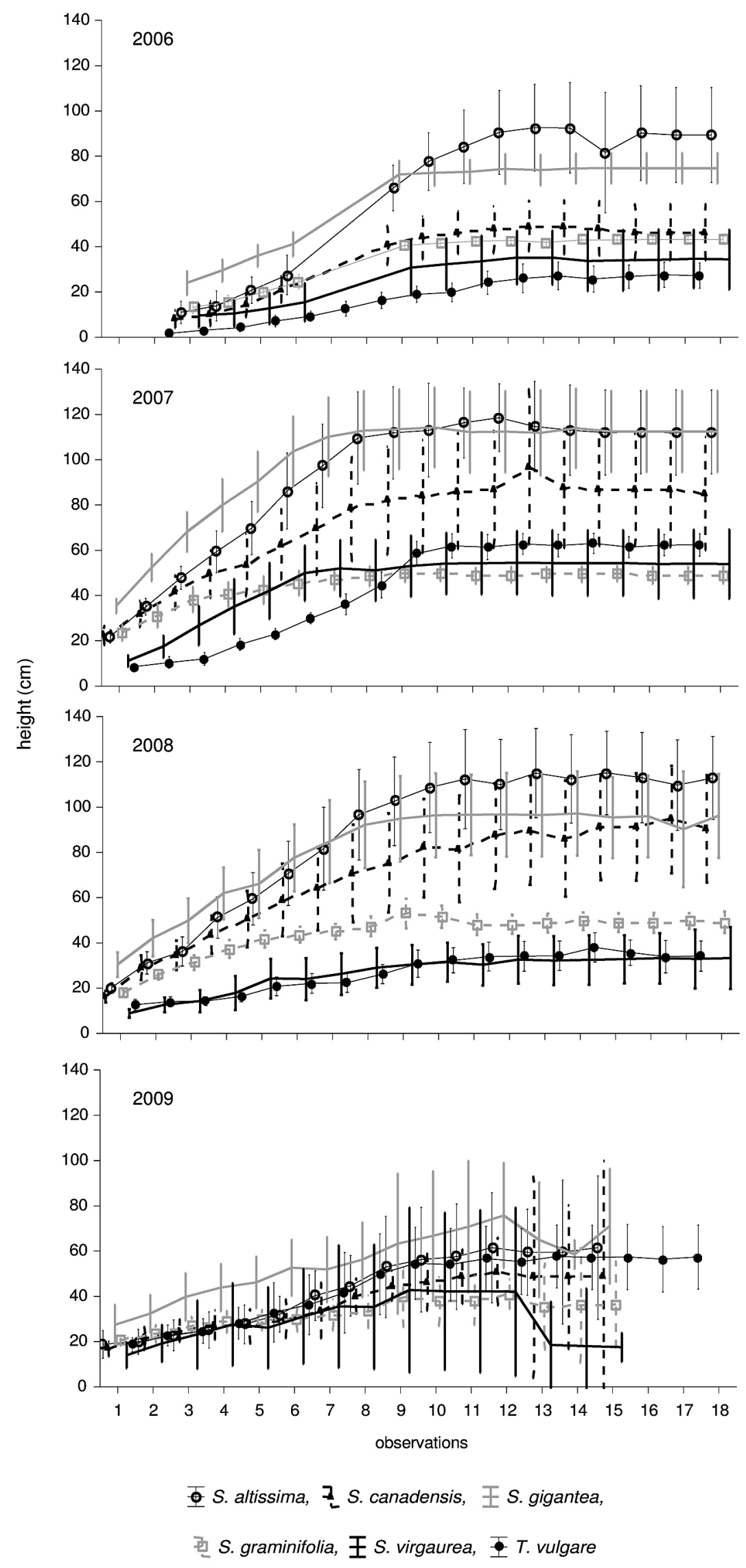

Fig. 1. Average height (central point) and 95\% confidence interval (whiskers) of different species' ramets at ten-day observation intervals. The observations were performed from May to October each year, each panel shows data for a given year. The averages are connected by lines 


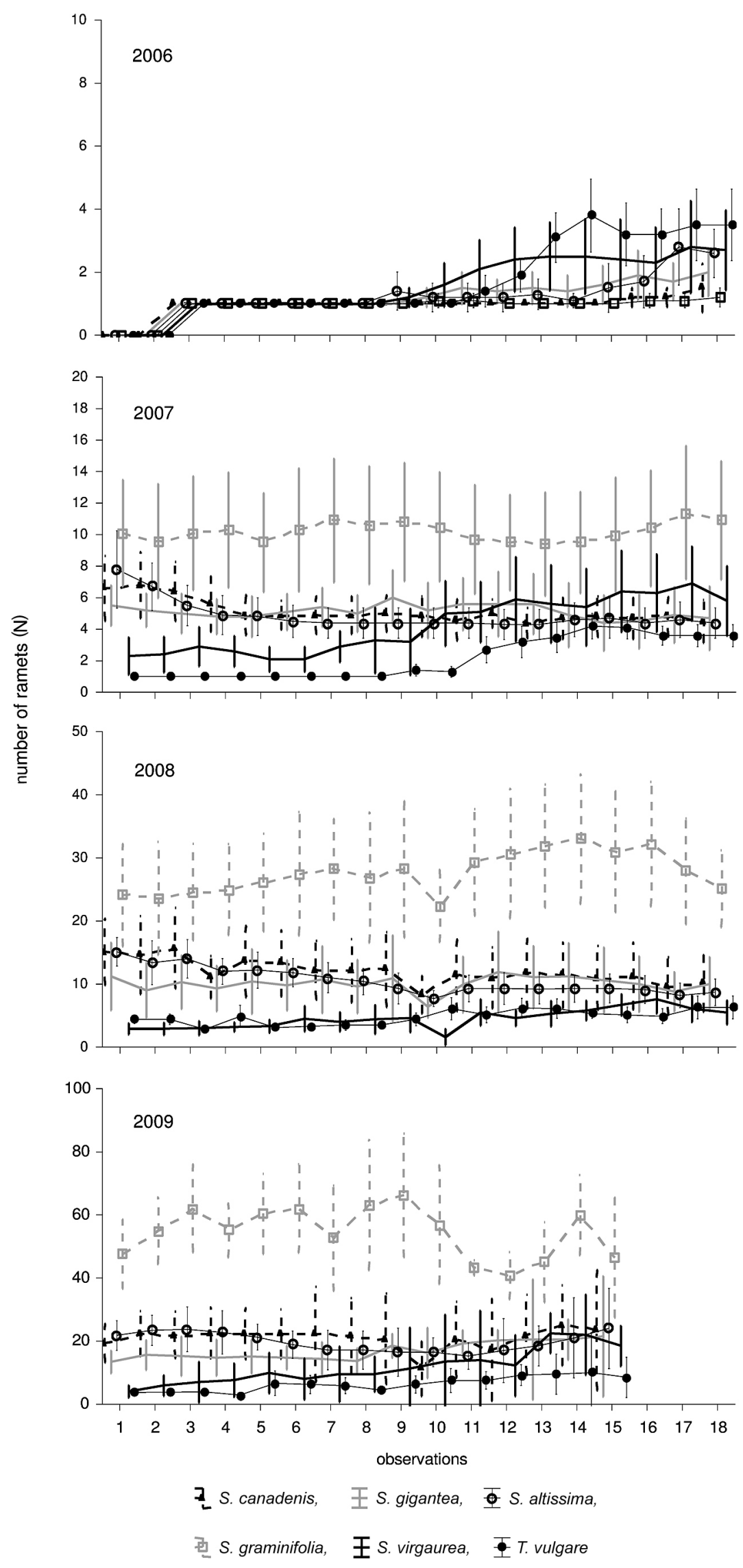

Fig. 2. Average number of ramets (central point) and 95\% confidence interval (whiskers) for different species at ten-day observation intervals. The observations were performed from May to October each year, each panel shows data for a given year. The averages are connected by lines. Note different ranges of the vertical axis in different years 

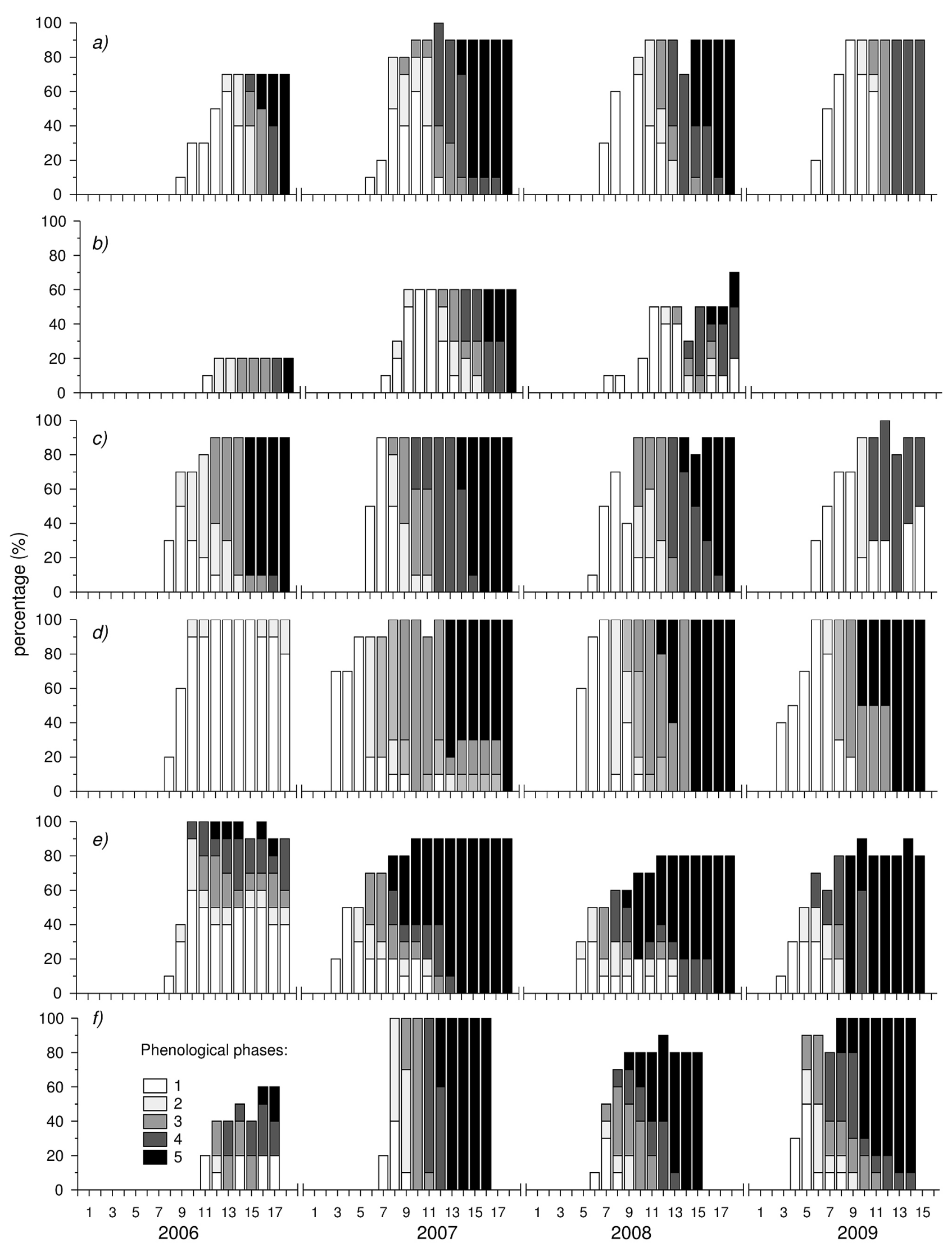

Fig. 3. Percentage of flowering shoots in phenological phases. Species: Solidago altissima (a), S. canadensis (b), S. gigantea (c), S. graminifolia (d), S. virgaurea (e) and Tanacetum vulgare (f). Measurements were done at ten-day intervals, performed from May to October each year. Phenological phases: 1 - appearance of generative shoots or buds of flowers, 2 - beginning of flowering, 3 - hight flowering, 4 - late flowering, 5 - seedset. For simplification, the phase 0 (only vegetative shoots) was not shown 
from 30 to $150 \mathrm{~cm}$ in S. canadensis and S. graminifolia (SEMPLE \& CooK 2006). The ramets of plants in our experiment were inside these ranges. The results of a comparative garden experiment, conducted in the USA (Schmid et al. 1988) and in our study, reveal a slightly different pattern of growth of S. altissima, $S$. canadensis and S. gigantea. It was found that in the native range, ramets of $S$. canadensis were more numerous, grew faster, flowered earlier and produced more mature seeds than S. altissima and S. gigantea (SCHMID et al. 1988). However, these species did not differ significantly in average height (SCHMID et al. 1988). We also did not observe differences in height among these three taxa, with the expection of the first year of the experiment (Fig. 1), where S. canadensis was lower than the two remaining species. Contrary to the results from the native range, we did not confirm differences in the number of ramets produced (Fig. 2). The phenological phases were also similar; however, our experiment shows that $S$. canadensis flowered later and produced a lower percentage of flowered ramets and mature seeds (Fig. 3).

The results of the experiment highlight a contrast between S. altissima, S. canadensis and S. gigantea on one hand and S. graminifolia on the other. The last species produced the highest number of ramets. Moreover, its phenology was more similar to native species than other alien Solidago, in accordance with the earlier time of flowering and seed ripening. Despite commonly being referred to by its European name (Solidago graminifolia (L.) Elliot.), the taxon should be classified as Euthamia Nutt. genus based on anatomical and DNA studies (SEmple et al. 1981, 1984) conducted in America. Therefore, its correct taxonomical name is Euthamia graminifolia (L.) Nutt. The differences in the analysed life history traits suggest the separateness of this species from other Solidago and confirm that it should be classified as another genus.

Our results imply strong competitive abilities of Solidago graminifolia because of its high ability to have both vegetative (high number of ramets) and generative (long period of flowering and the high percentage of seedset) reproduction. It is not in agreement with the actual range of this species, limited in Poland to the vicinity of the city of Opole. This species is considered as being in the 'lag phase' however; in recent years, its spread in different habitats in the south-western part of Poland has been observed (Dajdok \& Nowak 2006, Szymura \& Szymura 2013). Observations show that this species has broken the reproductive and dispersal barriers in the process of invasion. Therefore, monitoring and control of this species is essential to prevent its further distribution in Europe.

The phenology of flowering should be related not only to the ability of species to the invasion, but also to the environmental effect of the invader. The most widespread goldenrods (Solidago altissima, S. canadensis and S. gigantea) flower during late summer and early autumn when the flowers of the other honey plants are already overblown. On the contrary, the studied native species have a longer period of flowering (Fig. 3) which suggests that they are more useful for a higher number of pollinator species. The invasive Solidago species are potentially a good supplementary source of nectar for pollinators, especially honeybees (Apis mellifera L.) (MoroŃ et al. 2009, Hurej et al. 2012). However, the invasion of Solidago species has a negative effect on the abundance of wild pollinators (Moroń et al. 2009, Fenesi et al. 2015). The effect on honeybees differs in relation to landscape configuration. In a diverse landscape, patches of the invasive Solidago were unattractive (FENESI et al. 2015), while uniformly, in a human-dominated landscape, the number of honeybees was higher in patches of invaded vegetation (Moroń et al. 2009). Nevertheless, the abundance of honeybees, as domesticated species, is mostly regulated by beekeeper practices (Moroń et al. 2009). Since the invasion alters the mutualistic links between the pollinators and plants (Moroń et al. 2009, Fenesi et al. 2015), some programs preventing the goldenrods should be introduced (Moroń et al. 2009).

It is commonly accepted that disturbances which cause rapid resource release promote the invasive species (Hobbs \& HuenNeKe 1992, BobBinK et al. 1998, DAvis et al. 2000). The results of our experiment show that the native species $S$. virgaurea and Tanacetum vulgare exhibit more traits related to the $\mathrm{R}$ strategy (GRIME 2001) in that they produce relatively more flowering shoots and seeds during almost all growing seasons (Fig. 3). Moreover, they exceed the alien species in the number of the ramets produced just after establishing, during the first year of the experiment (Fig. 2). We consider it to be an adaptation of relatively high disturbance frequency. Thus, taking advantage of disturbances by invasive goldenrods is relative and could depend on the size of the disturbed area. In the case of abandoned fields, it was suggested that invasive species (e.g. Solidago gigantea) have an opportunity to dominate the vegetation when the disturbances are severe and cover relatively large areas (BARTHA et al. 2014). The species of mid-successional phases are promoted mostly by smaller-scale but frequent disturbances (BARTHA et al. 2014). Therefore, the observed differentiation in life history traits can explain why the large-scale field abandoning recently observed in Poland promotes invasive Solidago, while it is disadvantageous to the observed native species.

\section{CONCLUSIONS}

1. The highest ramets produced $S$. altissima, $S$. canadensis and S. gigantea, whereas S. graminifolia 
with native species: S. virgaurea and Tanacetum vulgare formed a group with lower ramets.

2. The most numerous ramets produced Solidago graminifolia. This species was flowered and produce mature seeds in $100 \%$ of ramets in the second year of the experiment. Moreover, their phenology is more similar to native species. These traits imply high invasive abilities of this species.

3. The time of flowering of Solidago altissima, S. canadensis and S. gigantea is late summer and early autumn, while the period for the native species and S. graminifolia is longer as it begins earlier.

\section{ACKNOWLEDGMENTS}

Sincere thanks for Mr. Janusz Urbański for his assistance in field works during whole experiment course. The study was supported by grants of Wrocław University of Environmental and Life Sciences and NCN (N N305 401438).

\section{REFERENCES}

Abrahamson W.G., Dobley K.B., Houseknecht H.R., Pecone C.A. (2005): Ecological divergence among five co-occurring species of old-field goldenrods. Plant Ecology 177: 43-56.

Alpert P., Bone E., Holzapfel C. (2000): Invasiveness, invisibility and the role of environmental stress in the spread of non-native plants. Perspectives of Plant Ecology, Evolution and Systematics 3(1): 52-66.

BAKER H.G. (1974): The evolution of weeds. Annual Review of Ecology and Systematics 5: 1-24.

Bartha S., Szentes S., Horváth A., Házi J., Zimmermann Z., Molnár C., Dancza I., Margóczi K., Pál R.W., Purger D., Schmidt D., Óvári M., Komoly C., SutyInszki Z., Szabó G., Csathó A.I., Juhász M., Penksza K., MoLnÁr Z. (2014): Impact of mid-successional dominant species on the diversity and progress of succession in regenerating temperate grasslands. Applied Vegetation Sciences 17: 201-213.

Bobbink R., Hornung M., Roelofs J.G. (1998): The effects of air-borne nitrogen pollutants on species diversity in natural and semi-natural European vegetation. Journal of Ecology 86: 717-738.

CHePLICK G.P. (1995): Genotypic variation and plasticity of clonal growth in relation to nutrient availability in Amphibromus scabrivalvis. Journal of Ecology 459-468.

DајDOK Z., NowAK A. (2006): Solidago graminifolia (L.) Elliott in Poland - spreading and habitat preferences. In: B. Tokarska-Guzik, K. Edwards (eds). Plant invasions. Backhuys Publishers, Leiden, The Netherlands: 20.

Davis M.A., Grime J.P., Thompson K. (2000): Fluctuating resources in plant communities: a general theory of invisibility. Journal of Ecology 88: 528-534.
De Groot M., Klejjn D., Jogan N. (2007): Species groups occupying different trophic levels respond differently to the invasion of semi-natural vegetation by Solidago canadensis. Biological Conservation 136(4): 612-617.

Dubicki A., Dubicka M., Szymanowski M. (2002): Klimat Wrocławia, In: K. Smolnicki, M. Szykasiuk (eds). Środowisko Wrocławia - Informator. Dolnośląska Fundacja Ekorozwoju, Wrocław: 9-20.

ERIKSSON O. (1989): Seedling dynamics and life histories in clonal plants. Oikos 55: 231-238.

Fenesi A., VÁGÁsi C.I., BeldeAn M., Földesi R., Kolcsár L.-P., Shapiro J.T., TÖRÖK E., KovÁcs-HostYÁnszKi A. (2015): Solidago canadensis impacts on native plant and pollinator communities in different-aged old fields. Basic and Applied Ecology 16: 335-346.

Goodwin B.J., McAllister A.J., Fahring L. (1999): Predicting invasiveness of plant species based on biological information. Conservation Biology 13: 422-426.

Grime J.P. (2001): Plant strategies, vegetation processes and ecosystem properties. Wiley, Chichester (United Kingdom).

Groves R. (1991): A short history of biological invasions of Australia. In: R. Groves, F. Di Castri (eds). Biogeography of Mediterranean invasions. Cambridge University Press, Cambridge: 59-63.

Guzikowa M., Maycock P.F. (1986): The invasion and expansion of three North American species of goldenrod (Solidago canadensis L. sensu lato, S. gigantea Ait. and S. graminifolia (L.) Salisb.) in Poland. Acta Societatis Botanicorum Poloniae 55: 367-384.

HobBs R.J., Huenneke L.F. (1992): Disturbance, diversity, and invasion: implications for conservation. Conservation Biology 6: 324-337.

Hurej M., Twardowski J., Łukowiak D., WilczyŃska K. (2012): Beneficial arthropods visiting Canada goldenrod (Solidago canadensis L.) in selected habitats in Wrocław area. Progress in Plant Protection 52(2): 335-339.

VAN KLEUNEN M., RichaRdson D.M. (2007): Invasion biology and conservation biology: time to join forces to explore the links between species traits and extinction risk and invasiveness. Progress in Physical Geography 31: 447-603.

van KleUNen M., SChMid B. (2003): No evidence for an evolutionary increased competitive ability in an invasive plant. Ecology 84: 2816-2823.

LAKE J.C., Leishman M.R. (2004): Invasion success of exotic plants in natural ecosystems: the role of disturbance, plant attributes and freedom from herbivores. Biological Conservation 117: 215$-226$.

Melville M.R., Morton J.K. (1982): A biosystematic study of the Solidago canadensis (Compositae) complex. I. The Ontario populations. Canadian Journal of Botany 60: 976-997. 
MeYer A., Schmid B. (1999): Seed dynamics and seedling establishment in the invading perennial Solidago altissima under different experimental treatments. Journal of Ecology 87: 28-41.

Moloney K.A., Holzapfel C., Tielbörger K., Jeltsch F., Schurr F.M. (2009): Rethinking the common garden in invasion research. Perspectives of Plant Ecology 11: 311-320.

Moravcová L., Pyšek P., Jarošík V., Pergl J. (2015): Getting the right traits: reproductive and dispersal characteristics predict the invasiveness of herbaceous plant species. PloS One 10(4):e0123634. doi: 10.1371/journal.pone.0123634.

Moroń D., Lenda M., Skórka P., Szentgyörgyi H., SetTELE J., WoyCiechowsKi M. (2009): Wild pollinator communities are negatively affected by invasion of alien goldenrods in grassland landscapes. Biological Conservation 142(7): 1322-1332.

PiLson D. (2000): Herbivory and natural selection on flowering phenology in wild sunflower, Helianthus annuus. Oecologia 122: 72-82.

Pyšek P., Jarošík V., Chytrý M., Kropáč Z., TichÝ L., WiLd J. (2005): Alien plants in temperate weed communities: Prehistoric and recent invaders occupy different habitats. Ecology 86: 772-785.

Pyšek P., Prach K., Smilauer P. (1995): Relating invasion success to plant traits: an analysis of the Czech alien flora. In: P. Pyšek, K. Prach, M. Rejmánek, M. Wade (eds). Plant invasions: general aspects and special problems. Academic Publishing, Amsterdam: 39-60.

PYšEK P., RichaRDson D.M. (2008): Invasive plants. In: S.E. Jørgensen, B.D. Fath (eds). Ecological engineering. Encyclopedia of ecology. Vol. 3. Elsevier, Oxford: 2011-2020.

PYšek P., Richardson D.M., Williamson M. (2004): Predicting and explaining plant invasions through analysis of source area floras: some critical considerations. Diversity and Distributions 10: 179$-187$.

RejMÁNeK M., Richardson D.M. (1996): What attributes make some plant species more invasive? Ecology 77(6): 1655-1661.

RotHMALER W. (2007): Exkursionsflora von Deutschland. Band 3. Elsevier, Spektrum Akademischer Verlag, München.

RUTKOwsKi L. (2013): Klucz do oznaczania roślin naczyniowych Polski niżowej. Wyd. Nauk. PWN, Warszawa.

Scharfy D., Eggenschwiler H., Venterink H.O., EdWARDS P.J., GÜSEWELL S. (2009): The invasive alien plant species Solidago gigantea alters ecosystem properties across habitats with differing fertility. Journal of Vegetation Sciences 20(6): 1072-1085.

Schlaepfer D.R., Glättli M., Fischer M., van Kleunen M. (2010): A multi-species experiment in their native range indicates pre-adaptation of invasive alien plant species, New Phytologist 185: 1087-1099 .

Schmid B., Puttick G.M., Burgess K.H., Bazzaz F.A. (1988): Correlations between genet architecture and some life history features in three species of Solidago. Oecologia 75: 459-464.

Semple J.C., Brammall R.A., Chmielewski J. (1981): Chromosome numbers of goldenrods, Euthamia and Solidago (Compositae-Asteraceae). Canadian Journal of Botany 59: 1167-1173.

Semple J.C., Cook R.E. (2006): Solidago. In: Flora of North America Editorial Committee (eds). Flora of North America. Oxford University Press, Oxford: 107-166.

Semple J.C., Ringius G.S., Leeder C., Morton G. (1984): Chromosome numbers of goldenrods, Euthamia and Solidago (Compositae-Asteraceae). II Additional counts with comments on cytogeography. Brittonia 36: 280-292.

Simberloff D., Martin J.L., Genovesi P., Maris V., Wardle D.A., Aronson J., Courchamp F., Galil B., García-Berthou E., Pascal M., Pyšek P., Sousa R., TABACCHI E., VILA M. (2013): Impacts of biological invasions: what's what and the way forward. Trends in Ecology and Evolution 28: 58-66.

SKóRKa P., Lenda M., TryJanowski P. (2010): Invasive alien goldenrods negatively affect grassland bird communities in Eastern Europe. Biological Conservation 143(4): 856-861.

SutHerLAND S. (2004): What makes a weed a weed: life history traits of native and exotic plants in the USA. Oecologia 141: 24-39.

Szymura M., Szymura T.H. (2011): Rozmieszczenie nawłoci (Solidago spp.) na obszarze Dolnego Śląska oraz ich wpływ na różnorodność biologiczną zasiedlanych fitocenoz. Acta Botanica Silesiaca 6: 195-212.

Szymura M., Szymura T.H. (2013): Environmental preferences and morphological diversity of goldenrods (Solidago L.) from south-western Poland. Acta Societatis Botanicorum Poloniae 82(2): 107$-115$.

ToKARsKA-GuzIK B. (2003): The expansion of some alien plant species (neophytes) in Poland. In: L.E. Child, J.H. Brock, G. Brundu, K. Prach, P. Pyšek, P.M. Wade, M. Williamson (eds). Plant invasions: ecological treats and management solutions. Backhuys Publishers, Leiden, The Netherlands: 147-167.

Vitousek P.M., Mooney H.A., Lubchenco J., Melillo J.M. (1997): Human domination of Earth's ecosystems. Science 277(5325): 494-499.

WALCK J.L., BASKIN J.M., BASKIN C.C. (1999): Effects of competition from introduced plants on establishment, survival, growth and reproduction of the rare plant Solidago shortii (Asteraceae). Biological Conservation 88: 213-219. 
WeBER E. (1997): Morphological variation of the introduced perennial Solidago canadensis L. sensu lato (Asteraceae) in Europe. Botanical Journal of the Linnaean Society 197: 197-210.

Weber E. (2001): Current and potential ranges of three exotic goldenrods (Solidago) in Europe. Conservation Biology 15: 122-128.

Weber E., Schmid B. (1998): Latitudinal population differentiation in two species of Solidago (Astera- ceae) introduced into Europe. American Journal of Botany 85: 1110-1121.

For citation: Szymura M., Szymura T.H. (2015): The dynamics of growth and flowering of invasive Solidago species. Steciana 19(3): 143-152. doi:10.12657/steciana.019.016 